\title{
Characterization of Potato Virus M epitopes with the use of synthetic peptides
}

\author{
S. S. Viter, T. Yu. Tkachenko, L. P. Kolomietz, Yu. L. Radavsky \\ Institute of Bioorganic and Petroleum Chemistry of Ukrainian National Academy of Science \\ Murmans'ka vul., 1, Kyiv, 02094, Ukraine \\ 1 Institute of Agricultural Microbiology of Ukrainian National Agricultural Academy of Science \\ Shevchenko vul., 97, Chernigov, 14027, Ukraine \\ E-mail: dsfp@antigen.kiev.ua
}

\begin{abstract}
As a result of thermolysin hydrolysis of a coat protein (CP) of Potato Virus $M$ Ukrainian Strain UI (PVM), the heptapeptide ${ }^{29}$ AADFEGK ${ }^{35}$ was found to be recognised by two PVM specific monoclonal antibodies (MAbs) M6D5 and M9GI. This heptapeptide represents the C-terminal part of tryptic tetradecapeptide ${ }^{22}$ EARPLPTAADFEGK ${ }^{35}(P / 4)$ which was also recognised by the same MAbs. The peptides represented sequences of tryptic $(P 14)$, thermolysinic $(P 7)$ fragments and three heptapeptides containing alanine substitutions for Asp ${ }^{31}$ and $\mathrm{Glu}^{33}$, were synthesised to determine the contribution of dicarbonic amino acids in the antigen-antibody interaction. All synthetic heptapeptides were recognised by both MAbs weakly in indirect ELISA. These peptides were also used as inhibitors of MAb-CP and $M A b-P 14$ reactions in inhibition ELISA. The results of inhibition ELISA have shown the following: 1) the same concentrations of peptides were more effective to inhibit the interaction of MAbs with P14 than with $C P ; 2)$ substitutions of charged amino acids decreased noticeably the ability of peptides to inhibit the antigen-antibody interaction, especially the substitution of $A s p^{31}$; 3) heptapeptides containing alanine substitutions suppressed more effectively the interaction of MAb M6D5 with antigens and were less effective to inhibit the reaction of $M A B M 9 G I$ with the same antigens. Thus, the difference in $A s p^{31}$ and Glu $^{33}$ contributions to the antigen-antibody complex formation has been found.
\end{abstract}

Introduction. Previously the antigenic analysis of two Potato Virus M Ukrainian strains (PVM U1 and U7) was carried out with the use of three monoclonal antibodies (MAbs M6D5, M9G1 and M4C1) [1]. The PVM-specific epitopes were established to be located in the N-terminal region of the coat protein (CP) and sequentially overlapped each other [1 ]. In that study the tryptic fragments ${ }^{22}$ Glu-Lys ${ }^{35}$ (PVM U1) and ${ }^{22}$ Gly-Lys ${ }^{35}$ (PVM U7) were recognised by two MAbs M6D5 and M9G1. The amino acid substitution Glu $\rightarrow$ $\rightarrow$ Gly at the position 22 of PVM U7 CP did not affect the antibody binding of the tryptic peptide and PVM U7 CP. It was shown that MAb M9G1 interfered with MAb M4C1 for binding PVM CP sites in the dot immunobinding assay. The synthetic peptide P14, corresponding to the tryptic fragment ${ }^{22}$ Glu-Lys ${ }^{35}$, inhibited the MAbs M6D5 and M9G1 interaction with

(C) S. S. VITER, T. Yu. TKACHENKO, . P. KOLOMIETZ, Yu. L. RADAVSKY, 2001
CP and peptide P14 with different level of ELISA inhibition. The modification of the side chain positive charge of $\mathrm{Lys}^{35}$ to negative one in tryptic peptides ${ }^{22}$ Glu-Lys ${ }^{35}$ and ${ }^{22}$ Gly-Lys ${ }^{35}$ using citraconic anhydride, resulted in two-fold increase of the MAb M9G1 reaction and slightly reduced the MAb M6D5 interaction with both fragments. On the basis of these results, it was concluded that: 1) PVM-specific epitopes are located at the $\mathrm{N}$-terminal region of PVM coat protein; 2) MAbs M6D5 and M9G1 recognise sequentially overlapping epitopes and the common part of both epitopes is presented in the ${ }^{22} \mathrm{Glu} / \mathrm{Gly}$ Lys $^{35}$ fragment; 3) MAbs M4Cl and M9G1 recognise either overlapping or conformational approximated epitopes. Also it was suggested that the region at position 34-49 of PVM CP is disposed to form the loop with $\pi$-turn [1].

In the present study the synthetic heptapeptides containing alanine substitutions of dicarbonic amino acids were used for more detailed analysis of PVM epitopes. 
Materials and Methods. Virus purification. PVM Ul strain was purified as described in $\{2\}$, using $50 \mathrm{mM} \mathrm{KH_{2 }} \mathrm{PO}_{4}-\mathrm{KOH}$ buffer with $5 \mathrm{mM}$ EDTA and $0.2 \% 2$-mercaptoethanol, $\mathrm{pH} 7.5$, and $0.3 \mathrm{M}$ glycine$\mathrm{KOH}$ buffer, $\mathrm{pH}$ 8.5. All purification procedures were performed at $4{ }^{\circ} \mathrm{C}$. The virus concentration was estimated assuming the extinction coefficient at $260 \mathrm{~nm}$ of $2.88 \mathrm{~cm}^{2} \cdot \mathrm{mg}^{-1}$. The $\mathrm{A}_{260 / 280}=1.21$, $A_{\max / \min }=1.12$ ratios [3] and SDS-electrophoresis [4] were used to analyse purity and quality of virus preparations. The purified virus were stored at $-20^{\circ} \mathrm{C}$ in $0.3 \mathrm{M}$ glycine- $\mathrm{KOH}$ buffer, $\mathrm{pH} 8.5$, containing $50 \%$ glyccrol.

Coat protein preparation. PVM U1 coat protein (CP U1) was prepared according to [5]. The purified virus at the concentration of $3-5 \mathrm{mg} / \mathrm{ml}$ in the $0.3 \mathrm{M}$ glycine-KOH buffer, $\mathrm{pH} 8.5$, was treated with the mixture of guanidine- $\mathrm{HCl}$ and $\mathrm{LiCl}$ at the final concentration of $4 \mathrm{M}$ and $2 \mathrm{M}$, respectively, and followed by freezing at $-70^{\circ} \mathrm{C}$ for $3 \mathrm{~h}$ and thawing at room temperature. The precipitated virus RNA was collected by centrifugation at $5000 \mathrm{~g}$ for $30 \mathrm{~min}$. The supernatant containing coat protein was dialysed

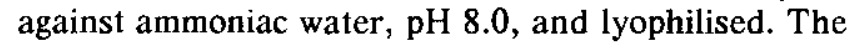
protein concentration was estimated according to Lowry et al. [6].

Proteolytic cleavage of PVM coat protein. CP U1 was digested with thermolysin («Sigma», USA) in $0.1 \mathrm{M}$ ammonium bicarbonate, $\mathrm{pH} 8.0$, at $37^{\circ} \mathrm{C}$ for $4 \mathrm{~h}$ at the enzyme-substrate ratio $1: 100(\mathrm{w} / \mathrm{w})$. The reaction was stopped by adding $0.1 \%$ acetic acid to $\mathrm{pH}$ 2.5. The thermolysin-treated proteins were stored at $-20{ }^{\circ} \mathrm{C}$.

Fractionation of thermolysinic peptides and sequencing. CP Ul thermolysinic mixture was fractionated by High Performance Liquid Chromatography (HPLC) on a C18 LiChrosorb RP-18 column (5 $\mu \mathrm{m}, 4.6 \mathrm{~mm} \times 250 \mathrm{~mm}$, «LKB», Sweden) using the $2-60 \%$ linear gradient of acetonitrile («Fluka», Switzerland) in $0.1 \%$ trifluoroacetic acid (TFA) at the flow rate of $1.0 \mathrm{ml} / \mathrm{min}$. Optical density was monitored at $206 \mathrm{~nm}$ and $280 \mathrm{~nm}$. The collected fractions were dried and peptide material of each fraction was dissolved in an appropriate buffer before using in further experiments.

The thermolysinic fractions found to be recognised by MÁbs were repeatediy fractionated using the same column and combination of linear gradient $(2-40 \%)$ and isocratic acetonirtile elution in $0.1 \%$ TFA. The amino acid sequence analysis was performed in a gas sequenator, model 816 («Knauer», Germany), according to the manufacturer protocol.

Peptide synthesis. Synthetic peptides P14 $\left(\mathrm{H}_{2} \mathrm{~N}-\right.$
${ }^{22}$ EARPLPTAADFEGK $\left.{ }^{35}-\mathrm{COOH}\right), \mathrm{P} 7\left(\mathrm{H}_{2} \mathrm{~N}-{ }^{29} \mathrm{AADF}-\right.$ $\left.\mathrm{EGK}^{35}-\mathrm{COOH}\right), \mathrm{Pl}\left(\mathrm{H}_{2} \mathrm{~N}^{29} \mathrm{AAAFEGK}^{35}-\mathrm{COOH}\right), \mathrm{P} 2$ $\left(\mathrm{H}_{2} \mathrm{~N}_{-}{ }^{29} \mathrm{AADFAGK}{ }^{35}-\mathrm{COOH}\right), \quad \mathrm{P} 3\left(\mathrm{H}_{2} \mathrm{~N}-{ }^{29} \mathrm{AAAFAG}-\right.$ $\mathrm{K}^{35}-\mathrm{COOH}$ ) and peptide $\mathrm{H}_{2} \mathrm{~N}^{154} \mathrm{KDASSSVF}^{161}-\mathrm{CO}$ $\mathrm{OH}$ as a negative control were synthesised (NPO Verta, St.-Petersburg, Russia) by the solid phase method using Boc-protected amino acids, according to [7].

ELISAs. Lyophilised protein and vacuum dried peptide samples were dissolved in phosphate buffered saline: $10 \mathrm{mM} \mathrm{Na} \mathrm{HPO}_{4}-\mathrm{NaH}_{2} \mathrm{PO}_{4}, \mathrm{pH} \mathrm{7.3}$, containing $0.14 \mathrm{M} \mathrm{NaCl}$ (PBS). Microtiter plates ("Nunk", Denmark) were coated with antigens hy evaporating PBS at $37^{\circ} \mathrm{C}$ overnight. Antigen-coated wells were rinsed with PBS and blocked with $1 \%$ BSA in PBS for $4 \mathrm{~h}$ at $37^{\circ} \mathrm{C}$. MAbs were diluted in PBS containing $0.05 \%$ Tween-20 (PBST) and $0.3 \%$ BSA and incubated with antigens for $2 \mathrm{~h}$ at $37^{\circ} \mathrm{C}$. After this the plates were washed five times with PBST, and the rabbit anti-mouse IgG-horse radish peroxidase conjugate $(1: 2000)$ in PBST with $0.3 \%$ BSA was added. The plates were incubated at $37^{\circ} \mathrm{C}$ for $1.5 \mathrm{~h}$ and washed five times with PBST. A colour reaction was developed by adding substrate buffer (0.1 M citrate-0.15 M Na $2 \mathrm{HPO}_{4}, \mathrm{pH} \mathrm{4.5),} \mathrm{containing}$ $0.6 \mathrm{mg} / \mathrm{ml}$ o-phenylenediamine («Fluka», Switzerland) and $0.01 \% \mathrm{H}_{2} \mathrm{O}_{2}$. ELISA optical density was measured at $450 \mathrm{~nm}$ using Kinetic Microplate Reader (Molecular Devices, «Fisher», USA).

In the inhibition ELISA experiments, MAbs were incubated with two-fold decreasing concentrations of synthetic peptides P14, P7, PI, P2 and P3 for $1 \mathrm{~h}$ at room temperature. Then these mixtures were added to the precoated antigens CP Ul $-500 \mathrm{ng}(14 \mathrm{pM})$ per well or peptide P14 $-50 \mathrm{ng}(33 \mathrm{pM})$ per well with following incubation for $1 \mathrm{~h}$ at $37^{\circ} \mathrm{C}$. The other steps of inhibition ELISA were performed as described above in ELISA procedure.

Further in the text all concentrations of antigens and inhibitors mean the amount of the material per well.

Monoclonal antibodies. MAbs M6D5, M4C1 and M9G1 were raised against native virus particles of PVM-Russian strain and were characterised earlier [8]. Professor M. Saarma, Institute of Chemical Physics and Biophysics (Estonia) has kindly provided the antibodies for this study.

Results and Discussion. For the further study of PVM antigenic structure the thermolysin hydrolysis of PVM CP was carried out. The products of proteolytic cleavage were fractionated by HPLC using linear acetonitrile gradient. The fractions collected were tested by indirect ELISA using three MAbs, M6D5, M4C1 and M9G1. MAb M4C1 did not re- 
cognise any thermolysinic fraction while MAbs M6D5 and $M 9 G 1$ reacted with fraction 17 . After additional HPLC purification using a combination of linear gradient and isocratic acetonitrile elution it has been shown, that fraction 17 consists of three subfractions: $17_{1}, 17_{2}$ and $17_{3}$. Only subfraction $17_{3}$ was recognised by MAbs M6D5 and M9G1 in ELISA. The primary structure of 17, subfraction peptide AADFEGK was established on a gas sequenator. The sequence of this heptapeptide corresponds to the fragment of PVM Russian strain CP [9] at the positions 29-35 and represents the $\mathrm{C}$-terminal part of tryptic tetradecapeptide ${ }^{22}$ EARPLPTAADFEGK ${ }^{35}$ that was also recognised by MAbs M6D5 and M9G1 [1].

In previous work [1] we pointed out that lack of reaction between $\mathrm{MAb} M 9 \mathrm{Gl}$ and lengthened peptides ${ }^{22} \mathrm{Glu} / \mathrm{Gly}-\mathrm{Arg}^{44}$ may be caused by structural changes in the C-terminal region of this fragment after protein cleavage by trypsin. These structural changes did not affect the recognition of ${ }^{22} \mathrm{Glu} / \mathrm{Gly}-\mathrm{Arg}^{44}$ peptides by MAb M6D5. The similar phenomenon, when the antibody recognised the short peptide and did not recognise the lengthened peptide, have been observed by other investigators $[10,11]$ and had no explanation until present. In our case we suggested that region ${ }^{34} \mathrm{Gly}-\mathrm{Asp}^{49}$ formed the loop with $\pi$-turn [12] and some of M9G1 epitope's amino acids were involved in the formation of this structure. The enzymatic destruction of PVM CP resulted in drastic distortions of the $\pi$-turn structure and abolished the recognition of M9G1 epitope in peptides ${ }^{22} \mathrm{Glu} / \mathrm{Gly}$ $\mathrm{Arg}^{44}$ by corresponding $\mathrm{MAb}$, whereas the main portion of M6D5 epitope located out of the $\pi$-turn structure and both peptides ${ }^{22} \mathrm{Glu} /$ Gly-Lys ${ }^{35}$ and ${ }^{22} \mathrm{Glu} /$ Gly-Arg ${ }^{44}$ were recognised by MAb M6D5. Thus, most likely, the M6D5 epitope is located at the $\mathrm{N}$-terminal part while M9G1 epitope is shifted to the C-terminal part of ${ }^{22} \mathrm{Glu} / \mathrm{Gly}-\mathrm{Arg}^{44}$ fragment [1 ].

On the basis of ELISA of thermolysinic fragments, the linear heptapeptide AADFEGK (P7) was synthesised. Additionally, the following peptides, containing alanine substitutions of charged amino acid were synthesised: 1) peptide AAAFEGK (P1) with $\mathrm{Asp}^{31} \rightarrow$ Ala substitution; 2) peptide AADFAGK (P2) with $\mathrm{Glu}^{33} \rightarrow$ Ala substitution; 3) peptide AAAFAGK (P3) with Asp $^{31} \rightarrow$ Ala and Glu ${ }^{33} \rightarrow$ Ala simultaneous substitutions. The alanine substitutions can help to find out the contribution of negatively charged amino acids in the MAb-antigen interaction. Generally accepted, that in most cases one amino acid substitution on the protein molecule surface resulted only in local changes, although the mutations are known that alter the distant regions conformation and thus have an indirect effect on antigenicity [13-16].
In indirect ELISA MAbs M6D5 and M9G1 reacted with $500 \mathrm{ng}(14 \mathrm{pM})$ of $\mathrm{CP}$ equally $\left(\mathrm{E}_{450}=2.5\right)$, while the reaction of MAb M6D5 with synthetic peptide P14 (50 ng or $33 \mathrm{pM}$ ) $\mathrm{E}_{450}=2.6$ was significantly higher then of MAb M9G1 $\left(E_{450}=1.4\right)$. The difference in reactions between MAbs and peptide P14 shows that only the part of M9G1 epitope is presented in peptide P14, whereas this peptide contains the most part of M6D5 epitope. Above mentioned concentrations of $\mathrm{CP}$ and peptide P14 were used as coating concentrations in inhibition ELISA.

Synthetic peptides (P7, P1, P2 and P3) were analysed in indirect and inhibition ELISA formats. In indirect ELISA MAbs M6D5 and M9G1 detected the peptide P7 at the minimal concentrations of $10 \mathrm{pM}$ (7 $\mathrm{ng}$ ) and $1 \mathrm{nM}(700 \mathrm{ng})$, respectively, while peptides $P 1, P 2$ and $P 3$ were not recognised by the antibodies at the concentration of $100 \mathrm{nM}$. The results of analysis of synthetic peptides P7, P1, P2 and P3 as coating antigens were highly contradictory and the level of MAbs reaction did not correlate with peptide concentrations.

This effect can be referred to very poor adsorption of short peptides to the plate material that leads to decrease or lack of ELISA reaction. Usually, to avoid such problem, the short peptides are used as inhibitors of the interaction between antibodies and antigens. In our study we used this approach to analyse the abilities of synthetic peptides P7, P1, P2 and $\mathrm{P3}$ to inhibit the reaction of MAbs M6D5 and M9G1 with PVM CP and synthetic peptide P14. Synthetic peptide ${ }^{155}$ DASSSVF $^{16 \mathrm{t}}$ was used as a negative control and displayed any inhibition capability in $\mathrm{MAb}-\mathrm{CP}$ and $\mathrm{MAb}-\mathrm{P} 14$ reactions.

The inhibition ELISA results showed that peptides P7, P1, P2 and P3 inhibited the interaction between MAbs and CP or P14 with various effectiveness. $50 \%$ inhibition of the M6D5-P14 and M9G1-P14 interactions was achieved using following concentrations of inhibitors $\left(\mathrm{C}_{50}\right): 17$ and $22 \mathrm{pM}$ of $\mathrm{P7}$ and $24 \mathrm{pM}$ and $12 \mathrm{nM}$ of $\mathrm{P} 14$, respectively (Fig. 1, 2). Maximum 95-96\% inhibition activity of peptide P7 was observed at concentration $390 \mathrm{pM}\left(\mathrm{C}_{\max }\right)$. In the range of $1.5-100 \mathrm{pM}$ concentrations of peptide P7 inhibited the reaction M9G1-P14 weaker, than the reaction M6D5-P14 (Fig. 1, lines 2 and 1 , respectively). The reaction M9G1-P14 was more effectively inhibited with peptide P7 (Fig. 1, line 2) than with peptide P14 (Fig. 2, line 3): $\mathrm{C}_{50}=22 \mathrm{pM}$ and $12 \mathrm{nM}$, respectively. Peptide $\mathrm{P} 7$ at the concentration of $390 \mathrm{pM}$ caused the $96 \%$ suppression of M9G1-P14 interaction (Fig. 1, line 2), while the same molar concentration of peptide P14 suppressed only $8 \%$ of this reaction (Fig. 2, line 3 ). $95 \%$ of P14 


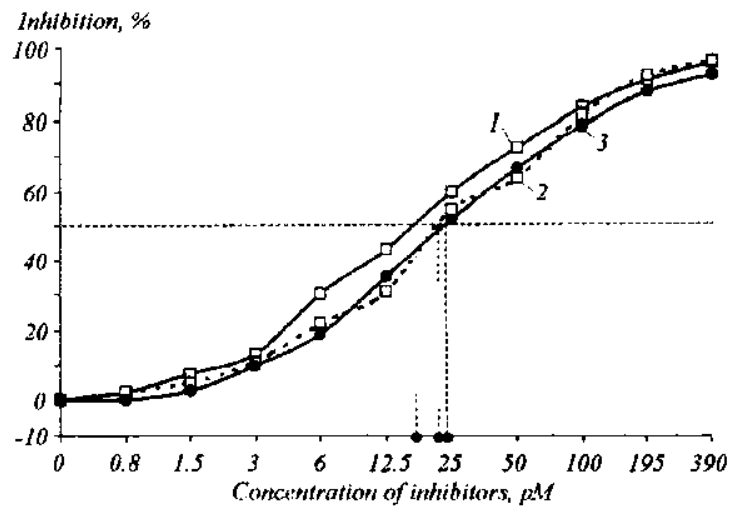

Fig. 1. Inhibition of M6D5-P14 and M9G1-P14 interactions with the use of synthetic peptides P7 and P14 as inhibitors. Lines: $l-$ inhibition of M6D5-P14 interaction by peptide P7; 2 - inhibition of M9G 1-P14 interaction by peptide P7; 3 - inhibition of M6D5-P14 interaction by peptide P14. Coating concentration of peptide P14 was $50 \mathrm{ng}(33 \mathrm{pM})$. MAbs were used at the next dilutions: M6D5 1:1000, M9G1 - 1:500. The vertical dotted lines (- - -) mark the inhibitor concentrations required for $50 \%$ inhibition of antibodyantigen interaction. Negative control data are not shown

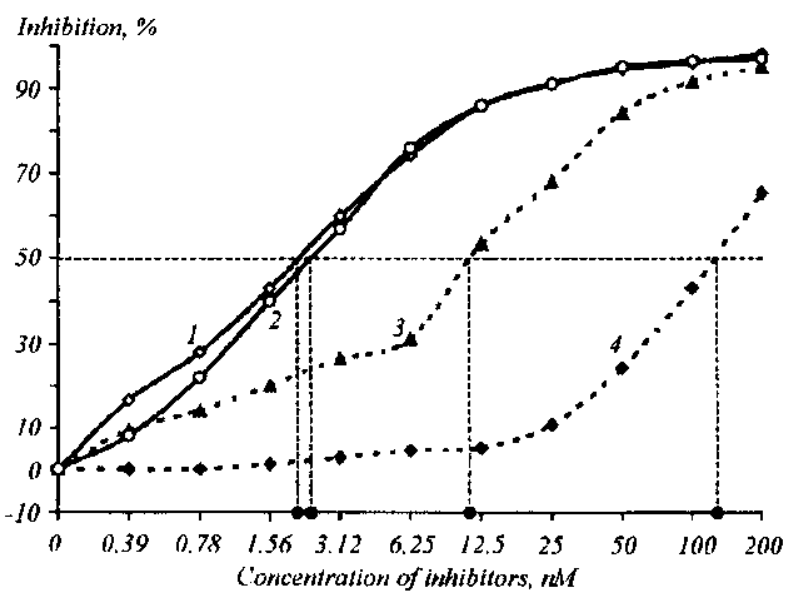

Fig. 2. Inhibition of MAbs-CP and MAbs-P14 interactions with the use of peptides P7 and P14 as inhibitors. Lines: 1 - inhibitor P14, interaction M6D5-CP; 2 - inhibitor P7, interaction M6D5-CP; $3-$ inhibitor P14, interaction M9G1-P14;4 - inhibitor P14, interaction M9G1-CP. Coating concentration of CP was $500 \mathrm{ng}(13 \mathrm{pM})$, of peptide P14-50 ng (33 pM). MAbs were used at the next dilutions: M6D5 - 1:1000, M9G1 - 1:500. Vertical dotted lines (- - -) mark the inhibitor concentrations required for $50 \%$ inhibition of the antibody-antigen interaction

inhibition effect was achieved at the concentration of $200 \mathrm{nM}$ (Fig. 2).

The higher concentrations of peptide P7 were required to inhibit the MAbs-CP interaction in com- parison with MAbs-P14. $50 \%$ inhibition of M6D5-CP reaction was achieved in the presence of 2.5 and 2.2 $\mathrm{nM}$ of peptides $\mathrm{P7}$ and $\mathrm{P14}$, respectively, and $\mathrm{C}_{\max }$ of both peptides were $200 \mathrm{nM}$ (Fig. 2, lines 1, 2). The interaction M9G1-CP was suppressed by $50 \%$ with $136 \mathrm{nM}$ of peptide P14 (Fig. 2, line 4). These results showed that conformation of peptide $\mathrm{P} 7$ was more appropriate for MAb M9G1 paratope while the peptide $\mathrm{P} 14$ was stronger inhibitor of reactions M6D5CP/P14.

The results of inhibition ELISA of MAbs-CP and MAbs-P14 interactions using peptides $\mathrm{P} 1, \mathrm{P} 2$ and $\mathrm{P} 3$ as inhibitors are presented in Fig. 3 and $4.50 \%$ inhibition of M6D5-P14 reaction (Fig. 3) was achieved at the concentrations of peptide P1 $10.5 \mathrm{nM}$ (line 2), $\mathrm{P} 2-5 \mathrm{nM}$ (line $J$ ), P3 - $100 \mathrm{nM}$ (line 5). The same inhibition effect of M6D5-CP reaction was observed at the following peptide concentrations: P1 - 36 nM (line 4), P2 - 17.5 nM (line 3); peptide $\mathrm{P} 3$ (line 6) did not show $50 \%$ inhibition at the used concentration range.

Peptides $\mathrm{P} 1, \mathrm{P} 2$ and $\mathrm{P} 3$ revealed poor inhibition abilities in M9G1-CP and M9G1-P14 reactions (Fig. 4), and only peptide $P 2$ suppressed reaction M9G1P14 at $\mathrm{C}_{50}=38 \mathrm{nM}$ (Fig. 4, line 1). Peptide P7 with an original sequence almost completely suppressed the interaction MAbs-P14 at $\mathrm{C}_{\max }=390 \mathrm{pM}$ (Fig. 1, lines $1,2)$, while peptide $\mathrm{P} 2$ at the concentration of $200 \mathrm{nM}$ showed $90 \%$ and $97 \%$ inhibition of M9G1-P14 (Fig. 4, line $I$ ) and M6D5-P14 (Fig. 3, line I) reactions, respectively. $200 \mathrm{nM}$ of peptide P2 suppressed by $92 \%$ and $35 \%$ reactions M6D5-CP (Fig. 3, line 3) and M9G1-CP (Fig. 4, line 2), respectively. Peptide P7 inhibited by $97 \%$ the M6D5-CP reaction (Fig. 2, line 2).

$200 \mathrm{nM}$ of peptide $\mathrm{Pl}$ containing the alanine substitution of aspartic acid inhibited by $94 \%$ and $10 \%$ the interactions M6D5-P14 (Fig. 3, line 2) and M9G1-P14 (Fig. 4, line 4), respectively. The same peptide inhibited by $83 \%$ and $2 \%$ the interaction M6D5-CP (Fig. 3, line 4) and M9G1-CP (Fig. 4, line 5), respectively.

Simultaneous substitution of $\mathrm{Asp}^{31}$ and $\mathrm{Glu}^{33}$ in peptide P3 decreased drastically the ability of this peptide to inhibit the reaction of MAbs with both antigens. At the concentration $200 \mathrm{nM}$ peptide $\mathrm{P} 3 \mathrm{did}$ not suppress completely any reaction, displaying $72 \%$ and $33 \%$ of inhibition in M6D5-P14 (Fig. 3, line 5) and M6D5-CP (Fig. 3, line 6) interactions, respectively. The reactions of $\mathrm{MAb} M 9 \mathrm{Gl}$ with $\mathrm{CP}$ and P14 were inhibited with $200 \mathrm{nM}$ of peptide P3 by $1 \%$ (Fig. 4, line 6) and $18 \%$ (Fig. 4, line 3), respectively.

Thus, the comparison of inhibition abilities of 


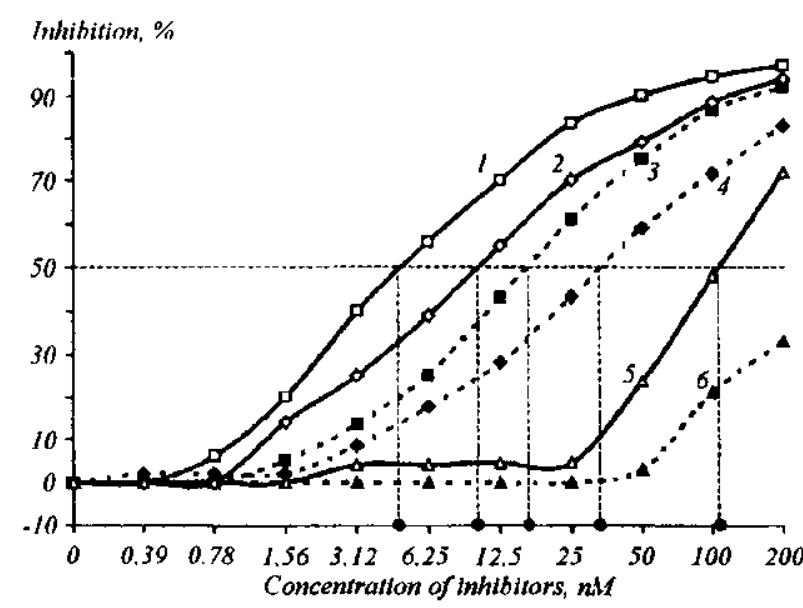

Fig. 3. Results of inhibition of interactions of MAb M6D5 with CP and P14 with the use of synthetic peptides with alanine substitutions as inhibitors. Lines: $I$ - inhibition of M6D5-P14 interaction by peptide P2; 2 - inhibition of M6D5-P14 interaction by peptide P1; 3 - inhibition of $\mathrm{M} 6 \mathrm{D5}-\mathrm{CP}$ interaction by peptide $\mathrm{P} 2 ; 4-$ inhibition of M6D5-CP interaction by peptide $\mathrm{P} 1 ; 5-$ inhibition of M6D5-P14 interaction by peptide P3; 6-inhibition of M6D5-CP interaction by peptide P3. Coating concentration of CP was $500 \mathrm{ng}$ (13 pM), of peptide P14 - $50 \mathrm{ng}(33 \mathrm{pM})$. MAb was used at the dilution 1:1000. Vertical dotted lines (- - ) mark the inhibitor concentrations required for $50 \%$ inhibition of the antibody-antigen interaction

peptides P7, P1, P2 and P3 showed that peptide P3 Asp $^{31} \rightarrow \mathrm{Ala}$ and $\mathrm{Glu}^{33} \rightarrow \mathrm{Ala}$ ) was the weakest. Peptide $\mathrm{P} 2\left(\mathrm{Glu}^{33} \rightarrow \mathrm{Ala}\right)$ maintained the highest residual inhibition activity in comparison with peptides $\mathrm{Pl}$ and P3. Peptide Pl (Asp ${ }^{31} \rightarrow$ Ala) also significantly affected the reactions of MAbs with both antigens. Peptides P1, P2 and P3 were more effective inhibitors of MAb M6D5-antigen reactions (Fig. 3) than MAb M9G1-antigen reactions (Fig. 4). The same inhibitor (peptides P14, P7, P1, P2, P3) concentrations more effectively suppressed the interactions MAbs-P14, than MAbs-CP. These data indicate that the native conformation and environment of this region in the protein molecule are very important for the interaction between MAbs and PVM epitopes, even if all critical residues of the epitopes are assumed to be located in the ${ }^{22}$ Glu-Lys ${ }^{35}$ region (peptide P14).

In present study the contribution of individual residues $\left(\mathrm{Asp}^{31}\right.$ and $\mathrm{Glu}^{33}$ ) in the MAb-antigen complex formation has been evaluated using the alanine substitutions. It has been established that both residues $\mathrm{Asp}^{31}$ and $\mathrm{Glu}^{33}$ are involved in the M6D5 and M9G1 epitopes and contribute differently to the formation of the antigen-antibody complexes. Asp $^{31}$ is more crucial residue of both epitopes than $\mathrm{Glu}^{33}$. Both amino acids $\mathrm{Asp}^{31}$ and $\mathrm{Glu}^{33}$ in M9G1 epitope are

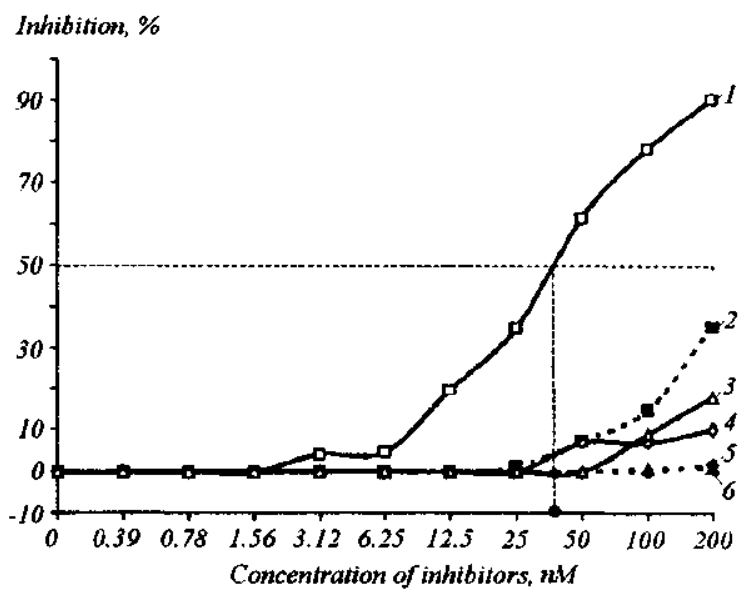

Fig. 4. Results of inhibition of the MAb M9G1 interactions with CP and P1 4 with the use of synthetic peptides with alanine substitutions as inhibitors. Lines: 1 - inhibitor P2, antigen $P 14 ; 2$ inhibitor $P 2$, antigen $C P ; 3-$ inhibitor $P 3$, antigen $P 14 ; 4$ - inhibitor $P 1$, antigen $P 14 ; 5-$ inhibitor $P 1$, antigen $C P$; $6-$ inhibitor $P 3$, antigen CP. Coating concentration of CP was $500 \mathrm{ng}(13 \mathrm{pM})$, of peptide P14 - $50 \mathrm{ng}(33 \mathrm{pM})$. MAb was used at the dilution 1:500. Vertical dotted lines (- - -) mark the inhibitor concentrations required for $50 \%$ inhibition of the antibody-antigen interaction

more important for recognition by corresponding MAb than the same residues in the structure of M6D5 epitope. The simultaneous substitution of $\mathrm{Asp}^{31}$ and $\mathrm{Glu}^{33}$ in the M9G1 epitope drastically decreases the recognition of this epitope by the antibody that shows the key role of these residues in the epitope, while M6D5 epitope in the absence of $\mathrm{Asp}^{31}$ and $\mathrm{Glu}^{33}$ residues partially reserves the ability to be recognised by the corresponding antibody. It is obvious that neighbour amino acids in the M6D5 epitope considerably contribute to the antigen-antibody complex formation.

Acknowledgements. The authors thank Professor Vladimir Kibirev for his critical reading and discussion of the manuscript. The authors thank Professor Mart Saarma for the monoclonal antibodies used in this study. S. Viter and T. Tkachenko contributed equally to this work.

С. С. вітер, Т. Ю. Ткаченкп, Л. П. Коломієць, ю. Л. Радавський

Характеристика епітопів М-вірусу картоплі з використанням синтетичних пептидів

Резюме

Після гідролізу білка оболонки (БО) українського щтаму UI 
М-вірусу кармоплі (РVM) термолізином виділено фрахмент АADFEGK ${ }^{3}$, який розпізнавався двома моноклональними антитілами (MKA) M6D5 та M9GI, специфіиними до PVM. Цей zеnmanenmuд $\epsilon$ С-кінцевою частицрю триптичного тетpadeкanenmudy ${ }^{22}$ EARPLPTAADFEGK ${ }^{35}$ (П14), який розпізнавався тими самими МКА. Для визначення внеску негативно заряджених дикарбонових амінокислот у формувания комплексу антиген-антитіло синтезовано синтетичні пептиди, ию повторюють послідовності триптицного (1114) та термолізинового (П7) фрагментів, а ракож гептапептиди, які містити заміни Asp3I та Glu на аланін. Усі синтетичні zептапептиди слабко взасмодіяли з обома МКА в непрямому ІФА. Ці пептиди використовували як інгібітори взасмодї МКА-БО і МКА-ЛJ4. Результати інгібування ІФА показали. що: 1) однакові концентрацї пептидів ефективніше інгибують взаємодію MKA 3 П14, ніж із $5 f ; 2$ ) заміна заряджених амінокислот, особливо заміна Аsp , значно зменшус здатність пептидів пригнічувати взасмодію антиген-антитіло; 3) zепmапептиди, цо містять заміни амінокислот на аланін, ефективніше пригнічують взаємодію $M K A$ M6D5 з антигенами та набагато слабие інгібують реакијо МKA М9GI з тими самими антигенами. Таким чином, Asp та Glu ${ }^{33}$ по-різному впливають на формування комплексу антиген-антитіло.

\section{С. С. витер, Т. Ю. Ткаченко, Л. П. Коломиеи, Ю. Л. Радавский}

Характеристика эпитопов М-вируса картофеля с

использованием синтетических пептидов

Резюме

После гидролиза белка оболочки (БО) украинского итамма UI М-вируса каррофеля (РVМ) термолизином выделен фрагмент ${ }_{\text {AADFEGK }}^{3}$, распознаваемый двумя моноклональными антителами (MKA) M6D5 и M9G1, специфичными к РVM. Этот zenmanenmud представляет собай С-конщевой участок mриптического тетрадекапептида ${ }^{22}$ EARPLPTAADFEGK ${ }^{35}$ (П14), распознаваемый этими же МКА. Для определения вклада отрицательно заряженных дикарбоновых аминокислот в формирование комплекса антиген-антитело синтезированы синтетинеские пептиды, повторяющие последовательности триптического (1714) и термолизинового (П7) фрагменmов, а также гепmanenтиды, содержацие замены Asp ${ }^{31}$ Glu на аланин. Все синтетические гептапептиды слабо взаимодействовали с обоими МКА в непрямом ИФА. Эти пептиды были использованы в качестве индибиторов реакций МКА-БО и МКА-П14. Результаты инсибирования ИФА показали, что: 1) одинаковые концентрации пептидов эффективнее ингибировали взаимодействие $М K A$ с $\Pi 14$, чем с БО; 2) замена заряженных аминокислот, особенно замена Asp , значительно снижала способность пептидов ингибировать взаимодействие антиген-антитело; 3) гептапептиды, содержащие замены аминокислот на аланин, жффективнее подавляли взаимодействие MKA M6D5 с антигенами и намного слабее ингибировали реакиню MKА M9GI с теми же антиzенами. Таким образом, Asp ${ }^{3}$ и Glu вносят различный вклад в формирование комплекса антиген-антитело.

\section{REFERENCES}

1. Viter S. S., Tkachenko T. Yu, Kolomictz L. P., Radavsky Yu. $L$ Analysis of antigenic structure of Potato Virus M Ukrainian strains // Biopolimery i Kletka (Biopolymers and Cell) (Kyiv) -2000 . -16.-P. 312-319.

2. Николаева О. В., Новиков В. К., Атабеков И. Г., Кафтанова $A . C$. Изменения антигенных свойств М-вируса картофеля при прогрессивной деградация структурного белка в процессе выделения и хранения // Сельскохозяйственная биология $-1985 .-10 .-$ C. $75-78$.

3. Tavantzis $S$. M. Physicochemical properties of Potato Virus M // Virology.-1984.-133.-P. 427-430.

4. Laemmli U.K. Cleavage of structural proteins during the assembly of the head of bacteriophage $\mathrm{T} 4$ // Nature. -1970 . 227. -P. $680-685$

5. Wu $G$. J., Bruening $G$. Two proteins from cowpea mosaic virus // Virology.-1971.-46.-P. 596-612.

6. Lowry O. H., Rosebrough N. J., Lewis F. A., Randall R. J. Protein measurement with the Folin phenol reagent // J. Biol. Chem.-1951.-193. -P. 265-275.

7. Barany G., Merrifield R. B. Solid-phase peptide synthesis // Peptides / Eds E. Gross, J. Meienhoter--New York: Acad. press, 1980.-Vol. 2.-P, 1-284.

8. Jarvekulg L., Sober J., Sinijarv R., Toots I., Saarma M. Time-resolved fluoroimmunoassay of potato virus M with monoclonal antibodies // Ann. Appl. Biol.--1989.-114.-P. 279291.

9. Zavriev $S . K$. Kanyuka $K . V$., Levay $K$. $E$. The genome organization of potato virus M RNA // J. Gen. Virol.-1991.72.-P. 9-14.

10. Muller S., Plaue S., Couppez M., Van Regenmortel M. H. V. Comparison of different methods for localizing antigenic regions in histone H2A // Mol. Immunol.-1986.-23.P. 593-601.

11. Joisson C., Kuster F., Plaue S., Van Regenmortel M. H. V. Antigenic analysis of bean pod mottle virus using linear and cyclized synthetic peptides // Arch. Virol.-1993.-128.P. 299-317.

12. Rajashankar. $K$. R., Ramakumar $S$. $\pi$-Turns in proteins and peptides: classification, conformation, occurrence, hydration and sequence // Protein Sci.-1996.-5.-.P. 932-946.

13. Benjamin D. C., Berzofsky J. A., East J. J., Gurd F. R. N., Hannum C., Leach S. J., Margoliash E., Michael J.G., Miller A., Prager E. M., Reichlin M., Sercaz E. E., Smith-Gill S. J., Todd $P$. E., Wilson $A$. C. The antigenic structure of proteins: a reappraisal // Ann. Rev. Immunol.-1984.-2.-P. 67101.

14. Al Moundallal Z., Briand J. P., Van Regenmortel M. H. V. Monoclonal antibodies as probes of the antigenic structure of tobacco mosaic virus // EMBO J.-1982.-1.-P. 10051010.

15. Blondel B., Crainic R., Fichot O., Dufraisse G., Candrea A., Diamond D., Girard $M$., Horaud $F$. Mutations conferring resistance to neutralization with monoclonal antibodies in type 1 poliovirus can be located outside or inside the antibodybinding site // J. Virol.-1986.-57.-P. 81-90.

16. Collawn J. F., Wallace C. J. A., Proudfoot A. E. F., Paterson $Y$. Monoclonal antibodies as probes of conformational changes in protein-engineered cytochrome $c / / \mathrm{J}$. Biol. Chem.1988.-263. -P. 8625-8634. 